\title{
Examining the Potential Impact of Race Multiplier Utilization in Estimated Glomerular Filtration Rate Calculation on African-American Care Outcomes
}

\author{
Salman Ahmed, MD, MPH ${ }^{7}$, , Cameron T. Nutt, MD², Nwamaka D. Eneanya, MD, MPH ${ }^{3}$, \\ Peter P. Reese, MD, MSCE ${ }^{3}$, Karthik Sivashanker, MD ${ }^{4,5}$, Michelle Morse, $M D, M P H^{2,6,7}$, \\ Thomas Sequist, MD, MPH ${ }^{2,8}$, and Mallika L. Mendu, MD, MBA 7,5,9
}

\begin{abstract}
'Division of Renal Medicine, Brigham and Women's Hospital, Harvard Medical School, Boston, MA, USA; '2Department of Medicine, Brigham and Women's Hospital, Harvard Medical School, Boston, MA, USA; ${ }^{3}$ Renal-Electrolyte and Hypertension Division, Perelman School of Medicine, University of Pennsylvania, Philadelphia, PA, USA; ${ }^{4}$ Department of Diversity, Inclusion, and Experience, Brigham and Women's Hospital, Boston, MA, USA; ${ }^{5}$ Department of Quality and Safety, Brigham and Women's Hospital, Harvard Medical School, Boston, MA, USA; ${ }^{6}$ EqualHealth, Tabarre, Haiti; ${ }^{7}$ EqualHealth, Brookline, MA, USA; ${ }^{8}$ Department of Quality, Patient Experience and Equity, Partners HealthCare, Boston, MA, USA; ${ }^{9}$ Center for Population Health, Partners HealthCare, Boston, MA, USA.
\end{abstract}

BACKGROUND: Advancing health equity entails reducing disparities in care. African-American patients with chronic kidney disease (CKD) have poorer outcomes, including dialysis access placement and transplantation. Estimated glomerular filtration rate (eGFR) equations, which assign higher eGFR values to African-American patients, may be a mechanism for inequitable outcomes. Electronic health record-based registries enable population-based examination of care across racial groups.

OBJECTIVE: To examine the impact of the race multiplier for African-Americans in the CKD-EPI eGFR equation on CKD classification and care delivery.

DESIGN: Cross-sectional study

SETTING: Two large academic medical centers and affiliated community primary care and specialty practices.

PARTICIPANTS: A total of 56,845 patients in the Partners HealthCare System CKD registry in June 2019, among whom 2225 (3.9\%) were African-American.

MEASUREMENTS: Exposures included race, age, sex, comorbidities, and eGFR. Outcomes were transplant referral and dialysis access placement.

RESULTS: Of 2225 African-American patients, 743 (33.4\%) would hypothetically be reclassified to a more severe CKD stage if the race multiplier were removed from the CKD-EPI equation. Similarly, 167 of 687 (24.3\%) would be reclassified from stage $3 \mathrm{~B}$ to stage 4 . Finally, 64 of 2069 patients (3.1\%) would be reassigned from eGFR $>20 \mathrm{ml} / \mathrm{min} / 1.73 \mathrm{~m}^{2}$ to $\mathrm{eGFR} \leq 20 \mathrm{ml} / \mathrm{min} /$ $1.73 \mathrm{~m}^{2}$, meeting the criterion for accumulating kidney transplant priority. Zero of 64 African-American patients with an $\mathrm{eGFR} \leq 20 \mathrm{ml} / \mathrm{min} / 1.73 \mathrm{~m}^{2}$ after the race multiplier was removed were referred, evaluated, or waitlisted for kidney transplant, compared to $19.2 \%$ of AfricanAmerican patients with $\mathrm{eGFR} \leq 20 \mathrm{ml} / \mathrm{min} / 1.73 \mathrm{~m}^{2}$ with the default CKD-EPI equation.

$\overline{\text { Statement of no Previous Publication The results presented in this }}$ paper have not been published previously in whole or part.

Received May 9, 2020

Accepted September 28, 2020

Published online October 15, 2020
LIMITATIONS: Single healthcare system in the Northeastern United States and relatively small AfricanAmerican patient cohort may limit generalizability.

CONCLUSIONS: Our study reveals a meaningful impact of race-adjusted eGFR on the care provided to the AfricanAmerican CKD patient population.

J Gen Intern Med 36(2):464-71

DOI: $10.1007 / \mathrm{s} 11606-020-06280-5$

(c) Society of General Internal Medicine 2020

\section{INTRODUCTION}

African-American chronic kidney disease (CKD) patients have poorer outcomes with respect to anemia and hypertension control, timely nephrology referral, dialysis fistula or graft placement, adequate dialysis treatment, and transplantation access compared with other racial groups. ${ }^{1-7}$ Notably, African-Americans have increased rates of end-stage renal disease (ESRD) compared with Whites, despite having similar or lower rates of CKD. ${ }^{8}$ The assignment of African-Americans to less severe CKD stages due to a race multiplier term in the estimated glomerular filtration rate (eGFR) equations may contribute to care delivery disparities. ${ }^{9,10}$ For example, the United Network for Organ Sharing encourages transplantation evaluation when eGFR is $20-30 \mathrm{ml} / \mathrm{min} / 1.73 \mathrm{~m}^{[2}{ }^{11}$ while other guidelines recommend referral at $\leq 20 \mathrm{ml} / \mathrm{min} /$ $1.73 \mathrm{~m}^{2}{ }^{12}$ Timely transplant referral has particular importance for African-Americans, who tend to have more rapid progression through CKD stages, and given that eGFR influences care delivery decisions, classification into less severe CKD stages could delay appropriate care.

Calculating eGFR based on serum creatinine allows for convenient assessment of kidney function and must account for the fact that filtration markers differ between individuals. ${ }^{13-15}$ The equations use surrogate markers of creatinine generation, such as age, sex, weight, and race. 
An association between African-American race with higher measured GFR at the same blood creatinine concentration has been demonstrated in large cohort studies, specifically, the Modification of Diet in Renal Disease (MDRD) study and the Chronic Kidney Disease Epidemiology Collaboration (CKD-EPI); both directly measure GFR with the gold standard marker of iothalamate. ${ }^{16,17}$ However, a clear biological explanation for this association is lacking, namely whether this finding represents differences in creatinine generation or excretion. Surrogates for generation such as height, weight, and race have been integrated in the MDRD and CKD-EPI equations to improve statistical precision. References of increased muscle mass in African-Americans compared to other racial groups are based on publications from the 1960s to the $1970 \mathrm{~s}$, which examined potassium content and bone densitometry in several hundred patients. ${ }^{18-20}$ The process for determining ethnicity for the MDRD study equation was "probably by examination of skin color." In the CKD-EPI study, which subsequently fit a more accurate eGFR equation, use of a race multiplier was justified for the same reason ${ }^{21,22}$ and the process of ascertaining race was unclear.

Key questions have been raised about the conceptual basis of the eGFR race multiplier. ${ }^{23-25}$ Some have questioned the validity of suggesting increased muscle mass in AfricanAmericans, highlighting historically racist language employed to define Blacks as biologically distinct from Whites. ${ }^{25} \mathrm{Sec}$ ond, race is used as a proxy for genetics, despite the fact that race is a social (not biologic) construct ${ }^{26}$ and evidence that racial differences in health are a product of structural racism. ${ }^{27}$ Third, there is genetic diversity within self-identified AfricanAmericans. ${ }^{28}$ Given potential issues for using race to estimate kidney function, we sought to examine the possible impact of the race multiplier term in the CKD-EPI equation on care delivery for African-Americans. Specifically, we focused on care delivery outcomes for advanced CKD patients, by leveraging a population-based database with detailed data on CKD care delivery measures.

\section{METHODS}

\section{Setting}

PHS includes two large academic medical centers and affiliated community practices in Massachusetts.

\section{Informed Consent}

The study was conducted under PHS Institutional Review Board exemption, meeting quality improvement research requirements.

\section{Partners HealthCare Chronic Kidney Disease Registry}

The development and validation of the PHS CKD registry has been previously described. ${ }^{29}$ Patients are included based on electronic health record (EHR) (EPIC systems, Verona, WI) clinical and billing data. Patients are classified as having CKD if they meet one of the following: (1) most recent eGFR $<60 \mathrm{ml} / \mathrm{min} / 1.73 \mathrm{~m}^{2}$ and one additional eGFR $<60 \mathrm{ml} / \mathrm{min} / 1.73 \mathrm{~m}^{2}$ at least 90 days prior; or (2) at least two values of urine total protein or urine albumin $>$ $300 \mathrm{mg} / \mathrm{g}$; or (3) ESRD or dialysis on problem list or as an International Classification of Diseases (ICD)-10 code. The PHS CKD registry utilizes the CKD-EPI equation to calculate eGFR, with an adjustment factor for AfricanAmerican race of eGFR multiplied by 1.159 , referred to subsequently as the "default equation." 22 The registry view displays eGFR using the default CKD-EPI equation; the individual lab view displays unadjusted eGFR with a note: "if patient is Black, multiply by 1.159 ." Data for this study were obtained in June 2019. Patients were excluded if they had undergone prior transplantation, were < 21 years old or $>100$ years old, or had previously received dialysis.

\section{Definitions}

Race was classified by self-identification, based on EHRbased demographic data, including classifications for White, Black/African-American, Hispanic, Asian, American Indian, or Alaska Native (AIAN), Hawaiian or Pacific Islander, Other, Not Available, or Declined. AIAN persons and Hawaiian or Pacific Islanders were grouped together, and blank, Other, Not Available, or Declined were grouped.

CKD staging was defined by Kidney Disease Improving Global Outcomes (KDIGO) guidelines. ${ }^{12}$ CKD stage 3 was defined as an eGFR of $30-59 \mathrm{ml} / \mathrm{min} / 1.73 \mathrm{~m}^{2}$; CKD stage 4 as an eGFR of $16-29 \mathrm{ml} / \mathrm{min} / 1.73 \mathrm{~m}^{2}$; and CKD stage 5 as an eGFR of $\leq 15 \mathrm{ml} / \mathrm{min} / 1.73 \mathrm{~m}^{2}$.

To examine differences in care with the race multiplier removed from the calculation of eGFR using the default CKD-EPI equation, we divided African-American patients' eGFRs by 1.159 .

\section{Metrics}

Comorbidity data were collected from EHR-based problem lists, and hypertension, diabetes, and congestive heart failure $(\mathrm{CHF})$ registries.

Blood pressure at goal was defined as systolic blood pressure $<140 \mathrm{mmHg}$ and diastolic blood pressure $<90 \mathrm{mmHg}$. ${ }^{29}$

The transplant status field is updated for individual patients by transplant coordinators for tracking and external reporting. Transplant status (none [default], referral, evaluation, waitlist, transplanted) exists in the CKD registry as a quality metric. ${ }^{20}$

"Access placement" is a registry metric, defined by a CPT code, ICD-10, or dialysis access documentation field within EHR for arteriovenous fistula, arteriovenous graft, or peritoneal dialysis catheter. ${ }^{29}$

Missing data are presented as proportion of patients with "unknown" outcomes for the blood pressure at goal metric. 


\section{Statistical Analysis}

Comparison of demographic and clinical characteristics was performed using ANOVA for comparison of means and Pearson's chi-squared test for comparison of proportions using STATA (produced by STATACorp, College Station, TX, USA, version 15).

We fit separate multivariable logistic regression models for (1) referral, evaluation, or waitlist status for kidney transplantation and (2) dialysis access placement. We adjusted for age, sex, race, and presence of diabetes mellitus, CHF, hypertension, and eGFR. We categorized patients into five mutually exclusive groups based on self-identified racial classifications and eGFR: (1) White with eGFR $\leq 20$; (2) Asian with eGFR $\leq$ 20; (3) African-American with eGFR $\leq 20$ using the default equation; (4) African-American with eGFR $\leq 20$ only with race multiplier removed; (5) no specified race with eGFR $\leq$ 20. There were substantially smaller numbers of Hispanics or AIANs with eGFR of $\leq 20$, and these groups were not included in this analysis; the total number of patients from the 5 included racial groups was $n=2101$.

Role of the Funding Source. Dr. Ahmed received support from the Brigham and Women's Department of Medicine Health Equity Improvement Program, and members of this program, including co-author Dr. Morse, provided study design guidance.

\section{RESULTS}

\section{Patient Demographics}

In a population of 56,845 patients included in the CKD registry, 2225 were African-American (Table 1). A higher proportion of African-Americans and Native Americans had advanced CKD (stage 4 or 5 ) at $16.7 \%$ and $22.6 \%$, respectively, compared to Whites at $10.8 \%$. The proportion of patients with hypertension was highest among African-Americans and Hispanics, at $88.1 \%$ and $89.8 \%$. Compared to Whites, other racial cohorts were significantly younger, had more severe CKD, and had a higher comorbidity burden.

\section{Reclassification to Early-Stage CKD}

With removal of the race multiplier, 434 patients were reclassified as having an eGFR of $52-60 \mathrm{ml} / \mathrm{min} / 1.73 \mathrm{~m}^{2}$, increasing the total number of African-Americans with CKD in our registry from 2225 to 2659 (an increase of 16\%).

\section{Reclassification to More Severe CKD Stage If Race Multiplier Removed}

Of 2225 African-Americans, a total of 743 (33.4\%) would experience a change to a more severe CKD stage if the race multiplier were removed (Table 2). In total, 167/687 (24.3\%) would be reclassified from stage 3B to stage 4 , with potential implications for kidney replacement therapy planning, such as referral for dialysis options education.

\section{Reclassification from eGFR $>20 \mathrm{ml} / \mathrm{min} / 1.73 \mathrm{~m}^{2}$ to eGFR $\leq 20 \mathrm{ml} / \mathrm{min} / 1.73 \mathrm{~m}^{2}$ If Race Multiplier Removed}

In total, 156/2225 (7.0\%) African-Americans had eGFR $\leq$ $20 \mathrm{ml} / \mathrm{min} / 1.73 \mathrm{~m}^{2}$ using the default equation (Table 3). Of these 156 patients, $30(19.2 \%)$ had a transplant referral, evaluation, or waitlist status. A total of 64/2069 (3.1\%) were reclassified from eGFR $>20 \mathrm{ml} / \mathrm{min} / 1.73 \mathrm{~m}^{2}$ to eGFR $\leq$ $20 \mathrm{ml} / \mathrm{min} / 1.73 \mathrm{~m}^{2}$ when the race multiplier was removed. None of these 64 patients had a transplant referral.

\section{Multivariable Logistic Regression Analysis of Care Measures for Advanced CKD (Those with eGFR $\leq 20 \mathrm{ml} / \mathrm{min} / 1.73 \mathrm{~m}^{2}$ )}

With regard to transplantation referral/evaluation/waitlist status, among patients with eGFR $\leq 20 \mathrm{ml} / \mathrm{min} / 1.73 \mathrm{~m}^{2}$ (using the default equation), African-American race was associated with significantly higher odds of referral than White race (OR 2.28, 95\% CI 1.39-3.75), adjusting for age, sex, eGFR, and presence or absence of diabetes mellitus, CHF, and hypertension. However, none of the African-Americans with eGFR $\leq$ $20 \mathrm{ml} / \mathrm{min} / 1.73 \mathrm{~m}^{2}$ with the race multiplier removed had transplant referral, evaluation, or waitlist status (Table 4 and Fig. 1). Older age and a diagnosis of CHF were associated with significantly lower odds of referral, and a diagnosis of hypertension was associated with increased odds of referral.

With regard to access placement, race was not associated with significantly different odds (Table 5). Older age and female sex were associated with significantly lower odds of access placement.

\section{DISCUSSION}

In this registry-based analysis of the impact of the CKD-EPI eGFR race multiplier for African-Americans, we have demonstrated that when the race multiplier is removed, up to one in three African-American patients would be reclassified to a more severe CKD stage. Nearly one in four AfricanAmericans would be reclassified to CKD stage 4 (from stage 3 ), which has implications for timely CKD management, referral to nephrology, and dialysis planning. By demonstrating that none of the African-Americans reclassified to eGFR $\leq$ $20 \mathrm{ml} / \mathrm{min} / 1.73 \mathrm{~m}^{2}$ had a transplant referral, we have highlighted the potential impact on care delivery based on small differences in eGFR. This finding indicates that nephrologists are utilizing race-adjusted eGFR in clinical decisionmaking, based on published guidelines.

Race has been treated as a biological variable associated with creatinine generation, similar to height, weight, and diet. ${ }^{12,15}$ Studies asserting that African-Americans have greater muscle 
Table 1 Demographic and Clinical Characteristics, by Racial Group, of Patients in the Partners HealthCare System Chronic Kidney Disease Registry

\begin{tabular}{|c|c|c|c|c|c|c|c|c|}
\hline & $\begin{array}{l}\text { White } \\
(n=49,150)\end{array}$ & $\begin{array}{l}\text { African- } \\
\text { American } \\
(n=2225)\end{array}$ & $\begin{array}{l}\text { Asian } \\
(n=1309)\end{array}$ & $\begin{array}{l}\text { Hispanic } \\
(n=609)\end{array}$ & $\begin{array}{l}\text { Native } \\
\text { American } \\
(n=80)\end{array}$ & $\begin{array}{l}\text { Other } \\
(n=3472)\end{array}$ & $\begin{array}{l}\text { Total } \\
(n=56,485)\end{array}$ & $\begin{array}{l}p \\
\text { value }\end{array}$ \\
\hline $\begin{array}{l}\text { Median age, in years } \\
\text { (interquartile range) }\end{array}$ & $77(15)$ & 73 (17) & $77(16)$ & $74(16)$ & 73 (14) & $76(16)$ & & \\
\hline Female sex, $n(\%)$ & $27,630(56.2)$ & $1370(61.6)$ & $688(52.6)$ & $\begin{array}{l}387 \\
(63.5)\end{array}$ & $47(58.8)$ & $2011(57.9)$ & $32,133(56.5)$ & \\
\hline $\begin{array}{l}\text { Payor, } n(\%) \\
\text { Medicare }\end{array}$ & $15,144(30.8)$ & $559(25.1)$ & $271(20.7)$ & $\begin{array}{l}171 \\
(28.1)\end{array}$ & 15 (18.8) & $791(22.8)$ & $16,951(30.0)$ & \\
\hline $\begin{array}{l}\text { Commercial } \\
\text { Medicare advantage } \\
\text { Medicaid } \\
\text { No payor listed }\end{array}$ & $\begin{array}{l}2512(5.1) \\
740(1.5) \\
259(0.5) \\
30,495(62.0)\end{array}$ & $\begin{array}{l}143(6.4) \\
10(0.4) \\
61(2.7) \\
1452(65.3)\end{array}$ & $\begin{array}{l}70(5.3) \\
13(1.0) \\
23(1.8) \\
932(71.2)\end{array}$ & $\begin{array}{l}23(3.8) \\
0(0.0) \\
30(4.9) \\
385 \\
(63.2)\end{array}$ & $\begin{array}{l}7(8.8) \\
0(0.0) \\
5(6.3) \\
53(66.3)\end{array}$ & $\begin{array}{l}139(0.5) \\
23(0.7) \\
59(1.7) \\
2460(70.9)\end{array}$ & $\begin{array}{l}2894(5.1) \\
786(1.4) \\
437(0.8) \\
35,777(62.9)\end{array}$ & \\
\hline $\begin{array}{l}\text { CKD stage, } n(\%) \\
\text { Stage } 3 \mathrm{~A}\end{array}$ & $27,915(56.8)$ & $1167(52.4)$ & $743(56.8)$ & $\begin{array}{l}363 \\
(596)\end{array}$ & $42(52.5)$ & $1897(54.6)$ & $32,127(56.5)$ & \\
\hline Stage 3B & $15,953(32.5)$ & $687(30.9)$ & $415(31.7)$ & $\begin{array}{l}183 \\
(30.0)\end{array}$ & $20(25.0)$ & $1134(32.7)$ & $18,392(32.4)$ & 0.28 \\
\hline $\begin{array}{l}\text { Stage } 4 \\
\text { Stage } 5 \\
\text { Diabetes, } n(\%)\end{array}$ & $\begin{array}{l}4606(9.4) \\
676(1.4) \\
14,032(28.5)\end{array}$ & $\begin{array}{l}295(13.3) \\
76(3.4) \\
1123(50.5)\end{array}$ & $\begin{array}{l}119(9.1) \\
32(2.4) \\
560(42.8)\end{array}$ & $\begin{array}{l}52(8.5) \\
11(1.8) \\
335 \\
(55.0)\end{array}$ & $\begin{array}{l}13(16.3) \\
5(6.3) \\
32(40.0)\end{array}$ & $\begin{array}{l}368(10.6) \\
73(2.1) \\
1259(36.3)\end{array}$ & $\begin{array}{l}5453(9.6) \\
873(1.5) \\
17,341(30.5)\end{array}$ & \\
\hline Hypertension, $n(\%)$ & $38,170(77.7)$ & $1961(88.1)$ & $1044(79.8)$ & $\begin{array}{l}547 \\
(89.8)\end{array}$ & $67(83.8)$ & $2533(73.0)$ & $44,322(78.0)$ & \\
\hline $\begin{array}{l}\text { Blood pressure at goal } \\
(<140 / 90), n(\%) \\
\text { Yes }\end{array}$ & $37,455(76.2)$ & $1594(71.6)$ & $952(72.7)$ & $\begin{array}{l}452 \\
(74.2)\end{array}$ & $56(70.0)$ & $2238(64.5)$ & $42,747(75.2)$ & \\
\hline $\begin{array}{l}\text { No } \\
\text { Unknown }\end{array}$ & $\begin{array}{l}3687(7.5) \\
8008(16.3)\end{array}$ & $\begin{array}{l}158(7.1) \\
473(21.3)\end{array}$ & $\begin{array}{l}100(7.6) \\
257(19.6)\end{array}$ & $\begin{array}{l}45(7.4) \\
112 \\
(18.4)\end{array}$ & $\begin{array}{l}7(8.8) \\
17(21.3)\end{array}$ & $\begin{array}{l}244(7.0) \\
990(28.5)\end{array}$ & $\begin{array}{l}4241(7.5) \\
9857(17.3)\end{array}$ & 0.88 \\
\hline $\begin{array}{l}\text { Congestive heart } \\
\text { failure, } n(\%)\end{array}$ & $9462(19.3)$ & $512(23.0)$ & $202(15.4)$ & $\begin{array}{l}108 \\
(17.7)\end{array}$ & $13(16.3)$ & $523(15.1)$ & $10,820(19.0)$ & \\
\hline
\end{tabular}

$p$ value $<0.005$ unless shown otherwise in table

mass than White patients include one study of 915 patients from Tennessee using total body neutron analysis that showed higher total body potassium content in African-American patients, and another study of 47 patients using the same technique. ${ }^{18-20}$ The MDRD study equation referenced these studies and directly measured GFR using the gold standard of iothalamate measurements. ${ }^{16}$ A total of 197 were classified as "Black," 1304 were classified as "White," and the remaining 127 were not defined. The authors state "Ethnicity was assigned by study personnel, without explicit criteria, probably by examination of skin color." The authors recognized that, "the prediction equation has been tested in relatively few black persons."

The use of racial classification in defining or calculating seemingly objective clinical data has faced criticism. Studies, such as a recent article by Vyas et al., detail the use of clinical calculators that integrate race, such as pulmonary function tests and a vaginal birth after cesarean section calculator, and their potential impact on health inequities ${ }^{30-32}$; the authors warn against the use of race as a proxy for genetic difference. Co-authors (NE and PR) highlighted that eGFR equations enable assessments of CKD prevalence over time in populations, but the inclusion of a race term creates problems at the bedside for patients who identify as mixed race or reject racial categorization. $^{24}$ There are examples of genetic inheritance informing kidney outcomes, such as the established association between the genetic mutation of apolipoprotein-1 (APOL1) and an increased risk of ESRD progression among some African-Americans with West African ancestry. ${ }^{33}$ Studies have indicated that APOL1 mutations account for over two-thirds of excess ESRD risk among African-Americans in the USA. ${ }^{34}$ Despite this evidence, most clinical laboratories are not performing APOL1 testing. ${ }^{35,36}$

Our study raises questions related to using the race multiplier to estimate kidney function. Notably, the PHS EHR has two views: (1) a registry view in which eGFR incorporates race adjustment; (2) lab view, with a note indicating eGFR should be multiplied by 1.159 in African-Americans; our findings suggest that clinicians were applying the race multiplier. Race-based eGFR calculation has major implications as it relates to care delivery, including drug dosing, nephrology referral, dialysis planning, and transplantation. Furthermore, it reinforces racist historical beliefs that African-Americans are inherently and biologically different than Whites. ${ }^{25}$

We focused intentionally on the risk of misclassification of disease severity for patients with advanced CKD, as opposed to early-stage CKD, to highlight examples of how small differences in estimating kidney function can lead to less care delivered. However, there are implications for patients with higher levels of eGFR, noted by authors Levey et al. ${ }^{37,38}$; specifically, they cite potential underestimation of eGFR in 
Table 2 Reclassification of African-American CKD Patients into Less Severe CKD Stages After Removal of Race Multiplier Term from CKDEPI Equation. Gray Shading and Bold Text Indicates Patients Who Are Reclassified. CKD, chronic kidney disease; $e G F R$, estimated glomerular filtration rate

\begin{tabular}{|c|c|c|c|c|}
\hline \multirow[b]{2}{*}{$\begin{array}{l}\text { eGFR categories using existing } \\
\text { eGFR equation(with race } \\
\text { multiplier term) } \\
\left(\mathrm{ml} / \mathrm{min} / 1.73 \mathrm{~m}^{2}\right), \mathrm{n}\end{array}$} & \multicolumn{4}{|c|}{ eGFR categories without race multiplier term $(\mathrm{ml} / \mathrm{min} / 1.73 \mathrm{~m} 2), \mathrm{n}(\%)$} \\
\hline & $\begin{array}{l}\text { CKD 3A } \\
\text { eGFR 45-59 } \\
(n=618)\end{array}$ & $\begin{array}{l}\text { CKD 3B } \\
\text { eGFR 30-44 } \\
(n=1069)\end{array}$ & $\begin{array}{l}\text { CKD } 4 \\
\text { eGFR 15-29 } \\
(n=435)\end{array}$ & $\begin{array}{l}\text { CKD } 5 \\
\text { eGFR }<15 \\
(n=103)\end{array}$ \\
\hline $\begin{array}{l}\text { CKD 3A } \\
\text { eGFR 45-59 } \\
(n=1167)\end{array}$ & $618(53)$ & $549(47)$ & & \\
\hline $\begin{array}{l}\text { CKD 3B } \\
\text { eGFR 30-44 } \\
(n=687)\end{array}$ & & $520(75.7)$ & $\begin{array}{l}167 \\
(24.3)\end{array}$ & \\
\hline $\begin{array}{l}\text { CKD } 4 \\
\text { eGFR 15-29 } \\
(n=295)\end{array}$ & & & $268(90.8)$ & $\begin{array}{l}27 \\
(9.2)\end{array}$ \\
\hline $\begin{array}{l}\text { CKD } 5 \\
\text { eGFR }<15 \\
(n=76)\end{array}$ & & & & 76 (100) \\
\hline Total $(n=2225)$ & & & & \\
\hline
\end{tabular}

Table 3 Reclassification of African-American Patients with eGFR $>20 \mathrm{ml} / \mathrm{min} / 1.73 \mathrm{~m}^{2}$ to $\leq 20 \mathrm{ml} / \mathrm{min} / \mathrm{m}^{2}$ After Removal of Race Multiplier Term from the CKD-EPI Equation. Gray Shading and Bold Text Indicates Patients Who Are Reclassified. CKD, chronic kidney disease; $e G F R$, estimated glomerular filtration rate

\begin{tabular}{|c|c|c|}
\hline & \multicolumn{2}{|c|}{$\begin{array}{l}\text { eGFR categories without race multiplier term } \\
\left(\mathrm{ml} / \mathrm{min} / 1.73 \mathrm{~m}^{2}\right), \mathrm{n}(\%)\end{array}$} \\
\hline $\begin{array}{l}\text { eGFR categories using existing eGFR } \\
\text { equation(with race multiplier term) } \\
(\mathrm{ml} / \mathrm{min} / 1.73 \mathrm{~m} 2), \mathrm{n}\end{array}$ & $\begin{array}{l}\text { eGFR }>20 \\
(n=2005)\end{array}$ & $\begin{array}{l}\text { eGFR } \leq 20 \\
(n=220)\end{array}$ \\
\hline $\begin{array}{l}\text { eGFR }>20 \\
(n=2069)\end{array}$ & 2005 (96.9) & $\begin{array}{l}64 \\
(3.1)\end{array}$ \\
\hline $\begin{array}{l}e G F R \leq 20 \\
(n=156)\end{array}$ & & $156(100)$ \\
\hline Total $(n=2225)$ & & \\
\hline
\end{tabular}


Table 4 Multivariable Logistic Regression Analysis for Outcome of Being Referred, Evaluated, or Waitlisted for Transplant for CKD Patients with eGFR $\leq 20 \mathrm{ml} / \mathrm{min}$ Across Racial Groups $(n=2101)$

\begin{tabular}{|c|c|c|c|}
\hline Variable & Odds ratio & 95\% confidence interval & $p$ value \\
\hline Age (per year) & 0.94 & $0.92-0.95$ & $<0.005$ \\
\hline Female sex (versus male sex) & 0.80 & $0.56-1.15$ & 0.23 \\
\hline Diabetes & 0.96 & $0.66-1.39$ & 0.81 \\
\hline Hypertension & 3.59 & $1.99-6.43$ & $<0.005$ \\
\hline Congestive heart failure & 0.65 & $0.42-1.01$ & 0.06 \\
\hline eGFR (per ml/min/1.73 m²) & 0.91 & $0.88-0.95$ & \\
\hline \multicolumn{4}{|l|}{ Race } \\
\hline White (reference) & 1.00 & & \\
\hline African-American (default equation eGFR $\leq 20$ ) & 2.28 & $1.39-3.75$ & $<0.005$ \\
\hline African-American eGFR $\leq 20 \mathrm{ml} / \mathrm{min}$ with removal of race multiplier & (0 events) & & \\
\hline Asian & 1.08 & $0.40-2.92$ & 0.88 \\
\hline Other & 0.89 & $0.46-1.72$ & 0.73 \\
\hline
\end{tabular}

African-Americans that could lead to overdiagnosis of CKD, inadequate medication dosing, and less access to specific therapies like sodium-glucose transporter 2 inhibitors or metformin, typically contraindicated at eGFR $<30 \mathrm{ml} / \mathrm{min} /$ $1.73 \mathrm{~m}^{2}$. Eliminating race from eGFR equations requires careful implementation and effective communication across health systems; for example, we found the total number of African-Americans classified as having CKD in our registry would increase by $16 \%$. We recognize that by removing the race multiplier, some of these patients may have an underestimation of eGFR, just as inclusion can lead to overestimation in others. However, this transition can be managed effectively. First, clinicians must recognize that regardless of race, eGFR is an imprecise measure at the patient level; in the CKD-EPI study, approximately $84 \%$ of measurements were within $30 \%$ of "true" measured GFR. ${ }^{21}$ Second, referral to nephrology should enable a thorough assessment of kidney function, appropriate counseling, and expert advice on medication dosing. What is known is many African-Americans face the challenge of more rapid acceleration to ESRD compared with other racial groups, so on average, they would likely benefit from earlier counseling and preparation for renal replacement therapy as well as earlier nephrology and transplant referral. The risk of underestimation versus overestimation must be recognized and mitigated by the use of biomarkers such as cystatin $\mathrm{C}$ that can estimate GFR without the use of race. ${ }^{39}$

\section{Special Note Regarding Transplantation}

We found that African-Americans with eGFR $\leq 20 \mathrm{ml} / \mathrm{min} /$ $1.73 \mathrm{~m}^{2}$ with the race multiplier applied had significantly higher rates of transplant referral compared to other patients; this may reflect recognition of faster progression to ESRD. However, African-Americans with an eGFR $\leq 20 \mathrm{ml} / \mathrm{min} /$ $1.73 \mathrm{~m}^{2}$ only with the race multiplier removed were never referred for transplantation ( $0 \%)$, compared to $19 \%$ using the default equation. This is an important finding, as the difference between a patient having an eGFR $\leq 20$ versus $>20 \mathrm{ml} / \mathrm{min} /$ $1.73 \mathrm{~m}^{2}$ with the race multiplier removed is approximately $3 \mathrm{ml} / \mathrm{min}$. This finding suggests that clinicians may be making

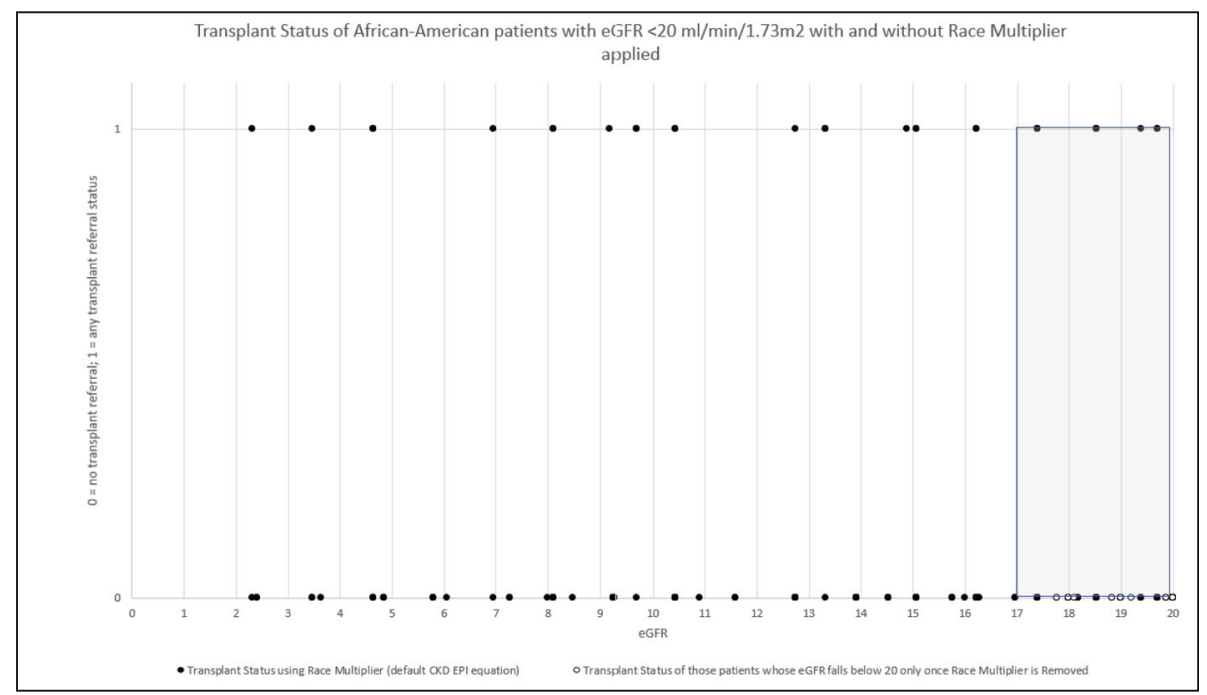

Fig. 1 Transplant status of African-American patients with eGFR $\leq 20 \mathrm{ml} / \mathrm{min} / 1.73 \mathrm{~m}^{2}$ with race multiplier applied (default equation, 156 patients and African-American patients with eGFR $\leq 20 \mathrm{ml} / \mathrm{min} / 1.73 \mathrm{~m}^{2}$ with race multiplier removed (64 patients) plotted by eGFR. Gray shading indicates patients with eGFR $17-20 \mathrm{ml} / \mathrm{min} / 1.73 \mathrm{~m}^{2}$. eGFR, estimated glomerular filtration rate. 
Table 5 Multivariable Logistic Regression Analysis for Outcome of Access Placement for CKD Patients with eGFR $\leq 20 \mathrm{ml} / \mathrm{min}$ Across Racial Groups $(n=2101)$

\begin{tabular}{|c|c|c|c|}
\hline Variable & Odds ratio & $95 \%$ confidence interval & $p$ value \\
\hline Age (per year) & 0.97 & $0.96-0.98$ & $<0.005$ \\
\hline Female sex (versus male sex) & 0.53 & $0.37-0.78$ & $<0.005$ \\
\hline Diabetes & 1.12 & $0.75-1.67$ & 0.59 \\
\hline Hypertension & 0.79 & $0.49-1.27$ & 0.34 \\
\hline Congestive heart failure & 1.64 & $1.08-2.50$ & 0.02 \\
\hline eGFR & 0.85 & $0.82-0.89$ & $<0.005$ \\
\hline \multicolumn{4}{|l|}{ Race } \\
\hline White (reference) & 1.00 & & \\
\hline African-American (default equation eGFR $\leq 20$ ) & 1.11 & $0.60-2.06$ & 0.74 \\
\hline African-American eGFR $\leq 20$ with removal of race multiplier & 1.85 & $0.41-8.28$ & 0.73 \\
\hline Asian & 0.65 & $0.19-2.19$ & 0.49 \\
\hline Other & 0.89 & $0.45-1.79$ & 0.75 \\
\hline
\end{tabular}

decisions with long-term implications based on small differences in physiologic parameters, which may have the unintended consequence of exacerbating disparities.

\section{Strengths and Limitations}

This study benefits from the utilization of a health systemwide registry capturing data from two large academic medical centers and community practices. We conducted a practical analysis of care delivered in the context of eGFR and the potential impact on important clinical outcomes. Finally, we sought input from nephrologists and health equity experts across our network.

The study's primary limitations stem from the limited geographic cohort, and relatively small proportion of AfricanAmericans and other racial minorities. Finally, patients who receive part of their care outside of our system could have incomplete outcome data. For example, it is possible that African-Americans are more likely to receive fragmented care, and we may underestimate care delivered. ${ }^{40,41}$ We also do not have data in our CKD registry about other delivery outcomes such as referral for dialysis modality education or goals of care discussions. Finally, our regression analyses are limited to age, sex, and relevant comorbidities and do not include adjustment based on other important attributes, such as socioeconomic status, due to limitations of the registry.

\section{Future Directions}

Our objective with this study is to quantify potential ramifications of racial assumptions and race-based eGFR equations on care delivered. We advocate for further epidemiologic study to better delineate whether there are differences in creatininebased eGFR based on social or ancestry-based differences. Based on this study and other efforts to advance health equity, nephrologists, health equity researchers, and health systems may consider eliminating race-adjusted eGFR, using biomarkers less dependent on race such as cystatin C, and testing genetic factors such as APOL1 across patients of all races. ${ }^{26}$ Efforts to advance "precision medicine," allowing for tailoring of diagnosis and treatment, can facilitate moving beyond biological race, ${ }^{42}$ and further efforts are needed to address structural racism. In the past few months, several health systems have decided to eliminate race-adjusted eGFR, including $\mathrm{PHS}^{43,44}$; those health systems should be aware of the implications of reclassification, including insurance coverage ramifications for those now diagnosed with CKD, and inclusion in drug trials. These health systems will need broad educational efforts led by nephrologists to guide management contingent on specific eGFR thresholds. Finally, for those who continue to utilize race-adjusted eGFR, it is important to be transparent with patients and account for flaws with classification. Patients should be informed about the use as they may not want racial categories applied to them, especially if it impacts the services they may not receive.

\section{CONCLUSIONS}

Racial disparities in CKD have been well described and continue to exist. It is important to consider that widespread, unexamined use of the race-adjusted eGFR equation may perpetuate and/or exacerbate these inequities but do not fully explain racial inequities, and CKD-specific health equity efforts are needed. Based on our findings, use of racial correction in eGFR can potentially impact care for AfricanAmerican patients with advanced CKD. Considering the evidence of this unfavorable impact on care delivery for AfricanAmericans, use of the eGFR race correction factor needs to be reconsidered and, at a minimum, providers should be transparent about its use.

Acknowledgments: The authors would like to acknowledge the Brigham and Women's Hospital Health Equity Improvement Program.

Corresponding Author: Salman Ahmed, MD, MPH; Division of Renal Medicine, Brigham and Women's Hospital, Harvard Medical School, Boston, MA, USA (e-mail: sahmed28@bwh.harvard.edu).

Authors' Contributions Drs. Ahmed and Mendu had full access to all the data in the study and take responsibility for the integrity of the data and the accuracy of the data analysis.

Drs. Ahmed, Morse, and Mendu contributed to the study concept and design. 
Dr. Ahmed contributed to acquisition of data.

All authors contributed to analysis and interpretation of data and drafting of the manuscript.

Funding This study was funded by a Brigham and Women's Hospital Department of Medicine Health Equity Improvement Program grant.

\section{Compliance with Ethical Standards:}

The study was conducted under PHS Institutional Review Board exemption, meeting quality improvement research requirements

Conflict of Interest: Dr. Mendu provides consulting service to Bayer $A G$, unrelated to this manuscript.

\section{REFERENCES}

1. Nzerue CM, Demissochew $\mathbf{H}$, Tucker JK. Race and kidney disease: role of social and environmental factors. J Natl Med Assoc 2002; 94 (8 Suppl): 28S-38S.

2. Crews DC, Charles RF, Evans MK, Zonderman AB, Powe NR. Poverty, race, and $\mathrm{CKD}$ in a racially and socioeconomically diverse urban population. Am J Kidney Dis 2010;55(6):992-1000.

3. Crews DC, Liu Y, Boulware LE. Disparities in the burden, outcomes, and care of chronic kidney disease. Curr Opin Nephrol Hypertens 2014;23(3):298-305

4. Sehgal AR, Abraham M. Health disparities and the kidney: introduction. Semin Nephrol 2010;30(1):1-2.

5. Gander JC, Zhang X, Plantinga L, Paul S, Basu M, Pastan SO, Gibney E, Hartmann E, Mulloy L, Zayas C, Patzer RE. Racial disparities in preemptive referral for kidney transplantation in Georgia. Clin Transpl 2018;32(9):e13380

6. Purnell TS, Luo X, Cooper LA, Massie AB, Kucirka LM, Henderson ML, Gordon EJ, Crews DC, Boulware LE, Segev DL. Association of Race and Ethnicity With Live Donor Kidney Transplantation in the United States From 1995 to 2014. JAMA. 2018;319(1):49-61.

7. Saunders MR, Lee H, Alexander GC, Tak HJ, Thistlethwaite JR, Ross LF. Racial disparities in reaching the renal transplant waitlist: is geography as important as race? Clin Transpl 2015;29(6):531-8.

8. Albertus P, Morgenstern H, Robinson B, Saran R. Risk of end-stage renal disease in the United States. AJKD. 2016; 68 (6): 862-872.

9. Norris K, Nissenson AR. Race, Gender, and Socioeconomic Disparities in CKD in the United States. JASN. 2008; 19 (7): 1261-1270.

10. Ortiz Z. Burden, access and disparities in kidney disease: chronic kidney disease hotspots and progress one step at a time. Clin Kidney J 2019; 12(2): 157-159.

11. https://unos.org/wp-content/uploads/unos/Kidney_Eval_Brochure.pdf Last Accessed 2/18/2020

12. KDIGO 2012 Clinical Practice Guideline for the Evaluation and Management of Chronic Kidney Disease. Kidney Int Suppl 2013; 3(1).

13. Stevens LA and Levey AS. Measured GFR as Confirmatory Test for Estimated GFR. JASN. 2009; 20 (11): 2305-2313.

14. Miller WG. Reporting estimated GFR: A laboratory perspective. Am J Kidney Dis 2008; 52: 645-648.

15. Stevens LA, Coresh J, Greene T, Levey AS: Assessing kidney function: Measured and estimated glomerular filtration rate. N Engl J Med 2006; 354: 2473-2483.

16. Levey AS, Bosch JP, Lewis JB, Greene T, Rogers N, Roth D. A More Accurate Method to Estimate Glomerular Filtration Rate from Serum Creatinine: A New Prediction Equation. Ann Intern Med 1999; 130 (6): 461-470.

17. Levey AS, Coresh J, Greene T, Stevens LA, Zhang Y, Hendriksen S Kusek JW, Van Lente F. Using Standardized Serum Creatinine Values in the Modification of Diet in Renal Disease Study Equation for Estimating Glomerular Filtration Rate. Ann Intern Med 2006; 145 (4): 247-254.

18. Cohn SH, Abesamis C, Zanzi I, Aloia F, Yasumura S, Ellis KJ. Body elemental composition: comparison between black and white adults. Am J Phys 1977; 232: E419-22.

19. Meneely GR, Heyssel RM, Ball COT. Analysis of factors affecting body composition determined from potassium content of 915 normal subjects. Ann N Y Acad Sci 110: 271-281, 1963.
20. Harsha DW, Frerichs RR, Berenson GS. Densitometry and anthropometry of black and white children. Hum Biol 1978; 50:261-80.

21. Levey AS, Stevens LA, Schmid CH, et al. A new equation to estimate glomerular filtration rate. Ann Intern Med 2009;150(9):604-612.

22. Levey AS, Stevens LA. Estimating GFR using the CKD Epidemiology Collaboration (CKD-EPI) creatinine equation: more accurate GFR estimates, lower CKD prevalence estimates, and better risk predictions. Am J Kidney Dis 2010;55(4):622-627.

23. Peralta CA, Risch N, Lin F, Shlipak MG, Reiner A, Ziv E, Tang H, Siscovick D, Bibbins-Domingo $\mathbf{K}$. The Association of African Ancestry and Elevated Creatinine in the Coronary Artery Risk Development in Young Adults (CARDIA) Study. Am J Nephrol 2010; 31(3): 202-208.

24. Eneanya ND, Yang W, Reese PP. Reconsidering the Consequences of Using Race to Estimate Kidney Function. JAMA. 2019; 322 (2): 113-114.

25. Grubbs V. Precision in GFR Reporting- Let's Stop Playing the Race Card CJASN May 2020, CJN.00690120

26. Yudell M, Roberts D, DeSalle R, Tishkoff S. Taking race out of human genetics. Science. 2016; 351 (6273): 564-565.

27. Jones CP. Levels of Racism: A Theoretic Framework and a Gardener's Tale. Am J Public Health 2000; 90(8): 1212-1215.

28. Martin T. The Color of Kidneys. AJKD. 2011; 58 (5): A27-A28

29. Mendu ML, Ahmed S, Maron JK, Rao SK, Chaguturu SK, May MF, Mutter WP, Burdge KA, Steele DJR, Mount DB, Waikar SS, Weilburg JB, Sequist TD. Development of an electronic health record-based chronic kidney disease registry to promote population health management. BMC Nephrol 2019; 20 (1): 72.

30. Kumar R, Seibold MA, Aldrich MC, et al. Genetic ancestry in lungfunction predictions. NEJM. 2010;363: 321-330.

31. Vyas DA, Jones DS, Meadows AR, Diouf K, Nour NM, Schantz-Dunn J. Challenging the Use of Race in the Vaginal Birth after Cesarean Section Calculator. Womens Health Issues 2019; 29(3): 201-204.

32. Vyas DA, Eisenstein LG, Jones DS. Hidden in Plain Sight Reconsidering the Use of Race Correction in Clinical Algorithms. NEJM July 2020.

33. Friedman DJ, Kozlitina J, Genovese G, Jog P, Pollak MR. Populationbased risk assessment of APOL1 on renal disease. JASN 2011; 22 (11) 2098-2105.

34. Genovese G, Friedman DJ, Ross MD, Lecordier L, Uzureau $\mathbf{P}$ Freedman BI, Bowden DW, Langefeld CD, Oleksyk TK, Knob AL, Bernhardy AJ. Association of trypanolytic ApoLl variants with kidney disease in African Americans. Science 2010; 329 (5993): 841-845.

35. Freedman BI, Limou S, Ma L, Kopp JB. APOL1-associated nephropathy: a key contributor to racial disparities in CKD. Am J Kidney Dis 2018 72 (5): S8-S16.

36. Udler MS, Nadkarni GN, Belbin G, Lotay V, Wyatt C, Gottesman O, Bottinger EP, Kenny EE, Peter I. Effect of Genetic Ancestry on eGFR and Kidney Disease. JASN. 2015; 26(7):1682-92.

37. Levey AS, Titan SM, Powe NR et al. Kidney Disease, Race, and GFR Estimation. CJASN May 2020, CJN. 12791019

38. Levey AS, Tighiouart H, Titan SM et al. Estimation of Glomerular Filtration Rate With vs Without Including Patient Race. JAMA Intern Med 2020;180(5):793-795.

39. Inker LA, Schmid $\mathbf{C H}$, Tighiouart $\mathbf{H}$ et al. Estimating glomerular filtration rate from serum creatinine and cystatin C. N Engl J Med 2012;367(1):20-9.

40. Kulkarni S, Ladin K, Haakinson D, Greene E, Li L, Deng Y. Association of Racial Disparities with Access to Kidney Transplant After the Implementation of the New Kidney Allocation System JAMA Surgery. 2019; 154 (7): 618-625.

41. Harding $\mathbf{K}$, Mersha TB, Vassalotti JA, Webb FJ, Nicholas SB. Current State and Future Trends to Optimize the Care of Chronic Kidney Disease in African Americans. Am J Nephrol 2017; 46 (2): 176-186.

42. Bonham VL, Callier SL, Royal CD. Will Precision Medicine Move Us beyond Race? N Engl J Med 2016; 374(21): 2003-2005.

43. https://www.nbcnews.com/health/health-news/medical-treatment-often-comes-racial-bias-here-s-how-some-n 1231477. Accessed 21 July 2020

44. https://www.asn-online.org/publications/kidneynews/archives/2020/ KN_2020_07_jul.pdf. Accessed 25 July 2020.

Publisher's Note: Springer Nature remains neutral with regard to jurisdictional claims in published maps and institutional affiliations. 